\title{
Hubungan Anemia Pada Ibu Hamil Dengan Antropometri Bayi Baru Lahir
}

\author{
Najwa Sufa Hilwa ${ }^{1}$, Irmiya Rachmiyani², Clpta Pramana ${ }^{3}$ \\ ${ }^{1}$ Mahasiswa Program Studi Sarjana Kedokteran Fakultas Kedokteran Universitas Trisakti; \\ ${ }^{2}$ Staff Pengajar Departemen Obstetri dan Ginekologi Fakultas Kedokteran Universitas Trisakti \\ ${ }^{3}$ Bagian Obstetri dan Ginekologi RSUD K.R.M.T Wongsonegoro Semarang/Dosen Pembimbing Klinis \\ Fakultas Kedokteran Universitas Trisakti Jakarta \\ Korespondensi: ${ }^{1}$ najwasufahilwa@hotmail.com ${ }^{2}$ dr.irmiya@trisakti.ac.id ${ }^{3}$ pramanacipta@yahoo.com
}

Submisi: 18 November 2019; Revisi: 15 Oktober 2020; Penerimaan: 16 Oktober 2020

\begin{abstract}
Background: Health problems that occur during pregnancy can affect the health of the baby in the womb until the delivery and growth of the baby. Anthropometry in newborns can be affected by some factors, which are anemia in pregnancy, the lack of maternal nutrition, maternal and fetal infections, and the mother contains multiple babies. Anemia in pregnant women will increase the risk of perinatal mortality and morbidity because it can cause impaired nutrition and utero placental oxygenation which results in a disruption of growth in conception.

Objective: This study aims to assess the relationship of anemia in pregnant women with anthropometry of newborns.

Method: Observational analysis with cross-sectional study design with subjects of research are pregnant women who gave birth in the hospital in January 2017 - June 2018. Variables collected and will be examined were Hb levels of the third semester, birth weight, birth length and baby head circumference born which was obtained from secondary data specifically medical records.

Result and Discussion: Total subjects in this study were 152 subjects, most of them were aged $26-30$ years (41.4\%) with mothers without anemia as many as 105 people (69.1\%). The results of the analysis show that there is no relationship between the weight of newborns and anemia in pregnant women, there is no relationship between the length of the newborn body and anemia in pregnant women, there is a relationship between the head circumference of newborns and anemia in pregnant women.

Conclusion: This study shows that there is a significant relationship between anemia in pregnant women with head circumference of newborns ( $p=$ 0.050 ), but it is found that there is no significant relationship between anemia in pregnant women and birth weight ( $p=0.374$ ) and body length of the baby $(p=0.198)$.
\end{abstract}

Keywords: Anemia; Anthropometry of newborns; Pregnant mother; Third trimester Hb level

\begin{abstract}
ABSTRAK
Latar Belakang: Gangguan kesehatan yang terjadi selama kehamilan dapat mempengaruhi kesehatan janin dalam kandungan hingga kelahiran dan pertumbuhan bayi selanjutnya. Antropometri pada bayi baru lahir dapat dipengaruhi oleh beberapa faktor yaitu anemia pada kehamilan, nutrisi maternal yang kurang, infeksi maternal dan fetal, dan ibu mengandung janin multipel. Anemia pada wanita hamil akan meningkatkan risiko mortalitas dan morbiditas perinatal karena dapat menyebabkan gangguan nutrisi dan oksigenasi utero plasenta yang menimbulkan gangguan pertumbuhan hasil konsepsi.

Tujuan: Penelitian ini bertujuan untuk menilai hubungan anemia pada ibu hamil dengan antropometri bayi baru lahir.

Metode: Analisis observasional dengan desain studi potong lintang dengan subjek penelitian ibu hamil yang melahirkan di RS pada bulan Januari 2017 - Juni 2018. Variabel yang dikumpulkan dan akan diteliti adalah kadar Hb trimester III, berat badan bayi lahir, panjang badan bayi lahir, dan lingkar kepala bayi lahir yang diperoleh dari data sekunder yaitu rekam medis.

Hasil dan Pembahasan: Total subjek pada penelitian ini adalah 152 subjek, sebagian besar subjek penelitian berusia 26 - 30 tahun (41,4\%) dengan ibu tidak anemia sebanyak 105 orang $(69,1 \%)$. Hasil analisis menunjukkan tidak ada hubungan antara berat badan bayi baru lahir dengan anemia pada ibu hamil, tidak ada hubungan antara panjang badan bayi baru lahir dengan anemia pada ibu hamil, ada hubungan antara lingkar kepala bayi baru lahir dengan anemia pada ibu hamil.

Kesimpulan: Penelitian ini menunjukkan bahwa terdapat hubungan bermakna antara anemia pada ibu hamil dengan lingkar kepala bayi baru lahir ( $p$ $=0,050)$, tetapi didapatkan tidak terdapat hubungan bermakna antara anemia pada ibu hamil dengan berat badan bayi lahir $(p=0,374)$ dan panjang badan bayi lahir $(p=0,198)$.
\end{abstract}

Kata kunci: Anemia; Ibu Hamil; Hemoglobin trimester III; Antropometri bayi 


\section{PENDAHULUAN}

Pembangunan dibidang kesehatan tidak bisa dilepaskan dari upaya mewujudkan kesehatan anak sedini mungkin sejak dalam kandungan. Upaya kesehatan ibu telah dipersiapkan sebelum dan selama kehamilan bertujuan untuk mendapatkan bayi yang sehat. ${ }^{1}$ Gangguan kesehatan yang terjadi selama kehamilan dapat mempengaruhi kesehatan janin dalam kandungan hingga kelahiran dan tumbuh kembang bayi selanjutnya. Gangguan kesehatan yang sering terjadi selama kehamilan adalah anemia. ${ }^{2}$ Anemia memiliki dampak yang besar terhadap kesehatan masyarakat, begitu juga pada perkembangan sosial dan ekonomi. Anemia terjadi di setiap tahap siklus hidup manusia, di mana satu dari empat orang di dunia menderita anemia. Risiko tertinggi anemia terdapat pada anak- anak yang belum bersekolah (0-4,99 tahun) dan ibu hamil. $^{2}$

Telatar B, dkk, menyatakan bahwa anemia maternal berpengaruh terhadap pengukuran antropometri (panjang lahir, berat lahir, lingkar kepala, dan lingkar dada). Terjadi perbedaan pada pengukuran antropometri dari ibu dengan anemia ringan dan ibu dengan anemia berat, pada ibu dengan anemia berat pengukuran antropometri bayi baru lahirnya lebih rendah daripada ibu dengan anemia ringan. ${ }^{3}$ Konsekuensi dari anemia selama kehamilan adalah hasil kehamilan yang buruk, gangguan perkembangan fisik dan kognitif, meningkatnya angka kesakitan pada anak, dan kurangnya produktivitas saat dewasa. Anemia selama kehamilan mempengaruhi pengukuran antropometri dari bayi yang baru lahir. Anemia yang berat secara signifikan akan memberikan efek negatif terhadap pengukuran antropometri neonatal. ${ }^{(3-4)}$

Berat badan lahir rendah (BBLR) dapat berdampak buruk pada kesehatan bayi. Permukaan tubuh bayi dengan berat lahir rendah relatif lebih luas, sehingga risiko kehilangan panas dan air relatif lebih besar. Selain itu, jaringan lemak subkutan bayi lebih tipis, sehingga risiko kehilangan panas melalui kulit dan kekurangan cadangan energi lebih besar. $^{(5,6)}$ Panjang bayi yang kurang dari normal saat kelahiran merupakan salah satu faktor risiko dari stunting. Stunting merupakan gangguan pertumbuhan linier dan apabila terjadi pada masa golden period perkembangan otak (0-3 tahun), maka berakibat pada perkembangan otak yang tidak baik. Hal tersebut di masa yang akan datang dapat berakibat pada penurunan kemampuan intelektual dan produktivitas, peningkatan risiko penyakit degeneratif dan kelahiran bayi dengan berat lahir rendah atau prematur. ${ }^{6}$

\section{METODE}

\section{Desain Penelitian}

Rancangan penelitian yang digunakan dalam penelitian ini adalah rancangan analisis observasional. Selanjutnya, data diolah dan diuji dengan menggunakan teknik analisis statistik.

Metode yang digunakan adalah desain potong silang atau cross sectional, berdasarkan hasil rekam medik ibu melahirkan di RSUD Budhi Asih dengan pertimbangan kriteria inklusi dan eksklusi. Penelitian akan dilaksanakan di RSUD Budhi Asih, Jakarta Timur pada bulan September 2018 sampai Desember 2018. Populasi yang dipilih adalah semua ibu yang melahirkan di RSUD Budhi Asih pada bulan Januari 2017 - Juni 2018.

\section{Besar Sampel dan Cara Pengukuran}

Sampel penelitian adalah anggota dari populasi yang memenuhi kriteria inklusi dan kriteria eksklusi. Teknik Pengambilan sampel adalah dengan cara consecutive sampling, yaitu dengan mengambil data yang memenuhi kriteria inklusi dan eksklusi yang berurutan dalam kurun waktu tertentu hingga memenuhi jumlah sampel yang dibutuhkan.

- Rumus populasi infinit

Keterangan:

$$
N o=\frac{Z \alpha^{2} P Q}{d^{2}}
$$

NO = besar sampel optimal yang dibutuhkan

$\mathrm{Z} \alpha=$ pada tingkat kemaknaan $95 \%$ besarnya 1,96

$\mathrm{P}=$ prevalensi bayi lahir normal $=0,90$

$\mathrm{Q}=1-\mathrm{p}$ (perkiraan prevalensi yang tidak tergolong $\mathrm{p}$ )

D = penyimpangan terhadap populasi atau derajat populasi yang dibutuhkan

Maka:

$$
\text { No }=\frac{(1,96)^{2} \times 0,90 \times 0,10}{(0,05)^{2}}=138
$$


- Rumus populasi finit

$$
n=\frac{n_{o}}{\left(1+\frac{n_{o}}{N}\right)}
$$

Keterangan:

$\mathrm{n}$ = besar sampel yang dibutuhkan untuk populasi finit

NO = besar sampel optimal yang dibutuhkan $=132$

$\mathrm{N}$ = besar populasi yang finit

(Ibu melahirkan Januari 2017 - Juni 2018)

Maka:

$$
n=\frac{138}{\left(1+\frac{138}{3608}\right)}=132
$$

Tabel 1 Distribusi Frekuensi Subyek Penelitian di RSUD Budhi Asih

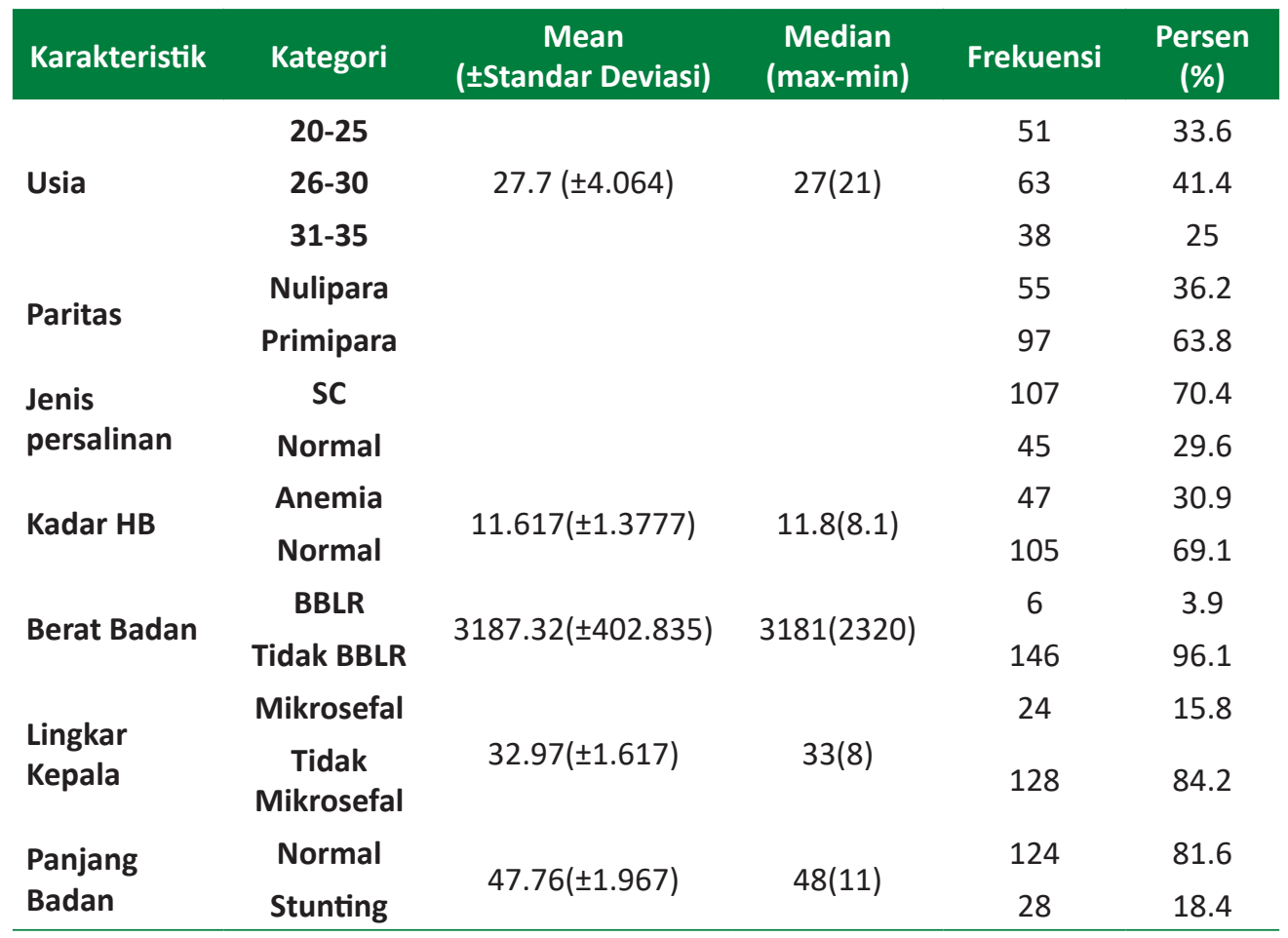

\begin{tabular}{|c|c|c|c|c|c|}
\hline & & \multicolumn{2}{|c|}{$\begin{array}{c}\text { Kadar } \mathrm{Hb} \text { trimester III } \\
\qquad \mathrm{N}=152\end{array}$} & \multirow[t]{2}{*}{ Total } & \multirow[t]{2}{*}{$p$-value } \\
\hline & & Anemia & Normal & & \\
\hline \multirow{2}{*}{ Berat Badan } & BBLR & 3 & 3 & 6 & \multirow{3}{*}{0.374} \\
\hline & Tidak BBLR & 44 & 102 & 146 & \\
\hline \multicolumn{2}{|c|}{ Total } & 47 & 105 & 152 & \\
\hline
\end{tabular}

Tabel 2 Hubungan Anemia dengan Berat Badan Bayi Lahir

Terlihat pada tabel di atas diketahui bahwa dari ibu yang memiliki kadar $\mathrm{Hb}$ trimester III dengan kategori anemia terdapat sebanyak 3 bayi terlahir dengan BBLR dan 44 bayi terlahir dari dengan Tidak BBLR. Sedangkan jika kadar Hb trimester III normal terdapat sebanyak 3 bayi terlahir dengan BBLR dan
Besar sampel adalah $132+$ drop out $(15 \% \times 132)=$ 152 responden. Sehingga minimal besar sampel penelitian adalah 152 responden.

\section{HASIL DAN PEMBAHASAN}

Data penelitian diambil dari data sekunder rekam medis ibu yang melahirkan di RSUD Budhi Asih, Jakarta Timur pada bulan Januari 2017 sampai Juni 2018. Responden yang diikutsertakan pada penelitian ini berjumlah 152 responden. 
Tabel 3 Hubungan Anemia dengan Panjang Badan Bayi Lahir

\begin{tabular}{lccccc} 
& & \multicolumn{2}{c}{ Kadar Hb trimester III } & & \\
\cline { 3 - 4 } & & \multicolumn{2}{c}{$\mathbf{N = 1 5 2}$} & Total & p-value \\
\cline { 3 - 4 } & & Anemia & Normal & & \\
Panjang & Normal & 35 & 89 & 124 & \\
Badan & Stunting & 12 & 16 & 28 & 0.198 \\
& Total & 47 & 105 & 152 & \\
\hline
\end{tabular}

Terlihat pada tabel di atas diketahui bahwa dari ibu yang memiliki kadar $\mathrm{Hb}$ trimester III dengan kategori anemia terdapat sebanyak 35 bayi terlahir dengan panjang badan normal dan 12 bayi terlahir dengan panjang badan stunting. Sedangkan jika kadar $\mathrm{Hb}$ trimester III normal terdapat sebanyak 89 bayi terlahir dengan panjang badan normal dan 16 bayi terlahir dengan panjang badan stunting. Hasil analisis statistik menunjukan nilai $p$-value $=0.198>$ 0.05 maka HO diterima, artinya dapat disimpulkan bahwa tidak ada hubungan antara panjang badan bayi baru lahir dengan kadar $\mathrm{Hb}$ trimester III.

Tabel 4 Hubungan Anemia dengan Lingkar Kepala Bayi Lahir

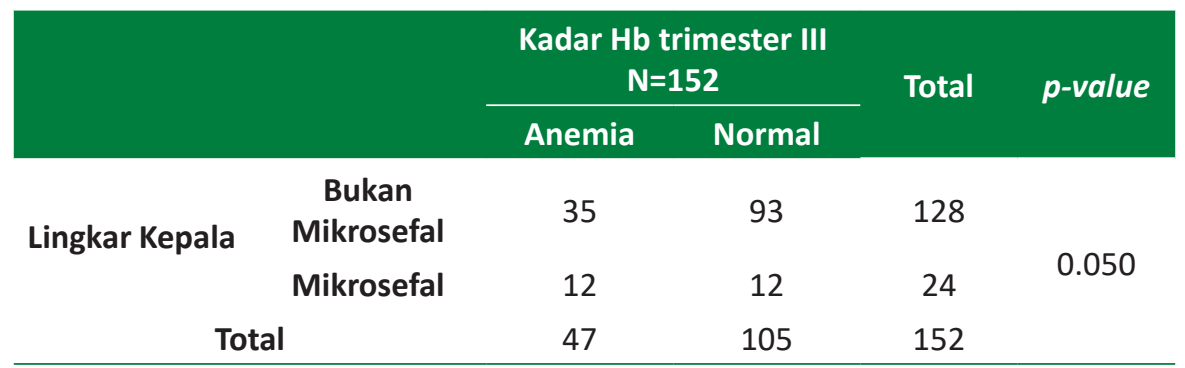

Terlihat pada tabel di atas diketahui bahwa dari ibu yang memiliki kadar $\mathrm{Hb}$ trimester III dengan kategori anemia terdapat sebanyak 35 bayi terlahir dengan lingkar kepala bukan mikrosefal dan 12 bayi terlahir dengan lingkar kepala mikrosefal. Sedangkan jika kadar Hb trimester III normal terdapat sebanyak 93 bayi terlahir dengan lingkar kepala bukan mikrosefal dan 12 bayi terlahir dengan lingkar kepala mikrosefal. Hasil analisis statistik menunjukan nilai p-value $=0.050 \leq 0.05$ maka $\mathrm{HO}$ ditolak, artinya dapat disimpulkan bahwa ada hubungan antara lingkar kepala bayi baru lahir dengan kadar $\mathrm{Hb}$ trimester III.

\section{Diskusi}

Dari 3.608 ibu hamil yang melakukan persalinan di RSUD Budhi Asih, Cawang selama Januari 2017 - Juni 2018, diambil sejumlah 152 sampel secara acak. Adapun karakteristik sampel yang dimasukkan dalam penelitian meliputi usia, paritas, dan jenis persalinan. Sebagian besar subjek penelitian berusia 26 - 30 tahun $(41,4 \%)$ dengan paritas terbanyak adalah primipara $(63,8 \%)$, dan jenis persalinan terbanyak adalah Sectio Caesaria (70,4\%).

\section{Hubungan antara Anemia dengan Berat Badan Bayi Lahir}

Pada penelitian ini, hasil analisis statistik menunjukan nilai $\mathrm{p}$-value $=0.374>0.05$ maka $\mathrm{HO}$ diterima, artinya dapat disimpulkan bahwa tidak ada hubungan antara berat badan bayi baru lahir dengan kadar $\mathrm{Hb}$ trimester III. Hasil penelitian ini sesuai dengan penelitian Ulfa $R^{7}$ yang juga menyatakan bahwa tidak ada hubungan antara kadar hemoglobin trimester III dengan berat badan bayi lahir. Hasil penelitian ini juga sesuai dengan penelitian yang dilakukan oleh Anggi $\mathrm{S}$, dkk ${ }^{8}$ yang menyatakan bahwa tidak terdapat hubungan signifikan antara kadar hemoglobin ibu hamil trimester III dengan antropometri bayi baru lahir, hal ini dikarenakan persamaan dalam pengambilan trimester untuk kadar $\mathrm{Hb}$ yaitu trimester III, dengan subjek pada usia yang relatif sama yaitu 20 - 35 tahun. Dengan ibu kehamilan trimester III yang melahirkan bayi aterm. Selain itu, terdapat persamaan tidak mengambil subjek ibu mengandung janin multipel, ibu dengan bayi yang mengalami kelainan kongenital, dan ibu perokok dan peminum alkohol. 
Hubungan kadar hemoglobin trimester III dengan berat bayi lahir memang telah dilaporkan pada beberapa penelitian. Kadar hemoglobin ibu hamil trimester III yang rendah dan tinggi dapat mengakibatkan pertumbuhan janin terhambat/ kecil untuk masa kehamilan. ${ }^{(9,10)}$ Pada penelitian ini, peneliti belum bisa menemukan hubungan antara anemia pada ibu hamil dengan berat bayi lahir tersebut. Hal ini terjadi dikarenakan masih adanya faktor-faktor lain yang mempengaruhi berat bayi lahir yang belum dapat disingkirkan sebagai faktor perancu pada penelitian seperti ibu hamil dengan berat badan $<45 \mathrm{~kg}$ dan nutrisi maternal yang kurang.

Pada dasarnya, berat bayi lahir memang tidak mutlak dipengaruhi oleh kadar hemoglobin ibu hamil. Berat bayi lahir dipengaruhi oleh dua faktor ibu yang mempengaruhi pertumbuhan janin intrauterin, yaitu faktor internal dan eksternal ibu hamil. Kadar hemoglobin termasuk ke dalam faktor internal ibu hamil. ${ }^{11}$

\section{Hubungan antara Anemia dengan Panjang Badan Bayi Lahir}

Pada penelitian ini, hasil analisis statistik menunjukan nilai $p$-value $=0198>0.05$ maka $\mathrm{HO}$ diterima, artinya dapat disimpulkan bahwa tidak ada hubungan antara panjang badan bayi baru lahir dengan kadar Hb Trimester III. Hasil penelitian ini didukung dengan hasil dari penelitian yang dilakukan oleh Laflamme EM. ${ }^{12}$ Pada penelitiannya didapatkan bahwa hubungan antara kadar hemoglobin ibu hamil dengan panjang badan bayi lahir memiliki $p$-value $>$ 0,05 , yang berarti tidak ada korelasi yang bermakna antara kedua variabel tersebut.

Penelitian ini sesuai dengan penelitian dari Ulfa $\mathrm{RP}^{13}$ yang menyatakan bahwa tidak terdapat hubungan antara kadar hemoglobin ibu hamil trimester III dengan panjang badan bayi lahir, hal ini dikarenakan persamaan dalam pengambilan trimester untuk kadar $\mathrm{Hb}$ dan juga persamaan dalam kriteria inklusi dan eksklusi. Namun, hasil penelitian ini berbeda dengan penelitian dari Rolla $D^{13}$ yang menyatakan ada hubungan antara anemia ibu hamil dengan panjang badan lahir pendek di puskesmas Sentolo 1 Kulon Progo. Ibu hamil yang mengalami anemia 4,13 kali lebih berisiko melahirkan anak dengan panjang badan lahir pendek dari pada ibu yang tidak anemia. ${ }^{13}$ Hasil penelitian yang berbeda dikarenakan banyak faktor seperti perbedaan metode penelitian, pada penelitian yang dilakukan oleh Rolla D menggunakan metode case control dengan jumlah sampel yang lebih sedikit yaitu 64 untuk bayi panjang lahir stunted dan 128 bayi kelompok kontrol, terdapat juga perbedaan dalam pengambilan trimester untuk kadar $\mathrm{Hb}$, pada penelitian ini mengambil status anemia pada ibu hamil yaitu kadar $\mathrm{Hb}$ trimester I hingga III.

\section{Hubungan antara Anemia dengan Lingkar Kepala Bayi Lahir}

Hasil analisis statistik menunjukan nilai $p$-value $=0.050 \leq 0.05$ maka HO ditolak, artinya dapat disimpulkan bahwa ada hubungan antara lingkar kepala bayi baru lahir dengan kadar Hb trimester III.

Hasil penelitian ini berbeda dengan yang didapatkan oleh Hutabarat $\mathrm{MR}^{5}$ melalui penelitiannya di RSUP Adam Malik Medan bahwa tidak ada hubungan antara kadar hemoglobin ibu hamil dengan lingkar kepala bayi lahir. Perbedaan dikarenakan jumlah sampel yang berbeda, pada penelitian menggunakan sampel dengan jumlah 45 sampel, dan tanpa mengeksklusikan faktor perancu lain, hanya mengeksklusikan ibu dengan janin multipel.

Studi oleh Telatar, $\mathrm{dkk}^{3}$, terhadap 3.6888 orang ibu hamil di Turki menyatakan bahwa lingkar kepala bayi lahir dipengaruhi secara negatif oleh anemia maternal, yang berarti bahwa anemia berat memiliki hubungan yang lebih signifikan. Penelitian tersebut mendapatkan perbedaan berat badan, panjang badan, lingkar kepala dan lingkar dada yang signifikan secara statistik di antara bayi baru lahir pada ibu hamil non anemia dan ibu hamil anemia. Berat badan, panjang badan, lingkar kepala, dan lingkar dada bayi dengan ibu hamil anemia berat memiliki nilai yang lebih kecil daripada ibu hamil anemia ringan. Perbedaan hasil penelitian dikarenakan perbedaan jumlah sampel yang signifikan, selain itu perbedaan karakteristik sampel dan demografis pada penelitian, dan perbedaan desain penelitian juga mempengaruhi hasil penelitian. 


\section{Keterbatasan Penelitian}

Dalam pelaksanaan penelitian ini, terdapat beberapa keterbatasan yang mungkin ikut mempengaruhi hasil penelitian yang ada. Keterbatasan itu berupa :

a. Tidak memasukkan faktor perancu lain seperti ibu dengan nutrisi maternal yang kurang dan ibu dengan berat badan $<45 \mathrm{~kg}$ sebelum kehamilan dalam kriteria eksklusi dikarenakan $>90 \%$ rekam medis tidak mencantumkan data tersebut.

b. Tidak mengambil data secara primer sehingga tidak bisa menanyakan hal yang belum tertera atau kurang jelas di rekam medis langsung kepada sampel.

c. Sampel yang diambil hanya dari satu rumah sakit sehingga tidak bisa membandingkan dengan populasi lain pada rumah sakit lainnya.

\section{KESIMPULAN DAN SARAN}

Berdasarkan hasil penelitian yang telah dilakukan maka dapat ditarik kesimpulan pada distribusi frekuensi sampel, diperoleh usia sampel paling banyak adalah 26-30 tahun, dan karakteristik hemoglobin paling banyak adalah normal. Tidak ada hubungan antara berat badan bayi baru lahir dengan kadar $\mathrm{Hb}$ trimester III. Tidak ada hubungan antara panjang badan bayi baru lahir dengan kadar $\mathrm{Hb}$ trimester III. Ada hubungan antara lingkar kepala bayi baru lahir dengan kadar $\mathrm{Hb}$ trimester III.

\section{DAFTAR PUSTAKA}

1. Departemen Kesehatan RI. Profil kesehatan Indonesia. Depkes RI. 2009: Jakarta

2. Departemen Kesehatan RI. Pedoman pelaksanaan stimulasi, deteksi, dan intervensi dini tumbuh kembang anak di tingkat pelayanan kesehatan dasar. Bakti Husada. 2008: Jakarta.
3. Telatar B, Comert S, Vitrinel A, Erginoz E, Akin Y. The effect of maternal anemia on anthropometric measurements of newborns. Saudi Med J. 2009; 30(3): 409-12

4. Dandara S, Hariati L, Ririn Teguh A. Analisis Faktor Risiko BBLR, Panjang Badan Bayi Saat Lahir dan Imunisasi Dasar Terhadap Kejadian Stunting pada Balita Usia 12-36 Bulan. Universitas Halu Oleo. 2016

5. Margareth R. M. Hutabarat. Hubungan Kadar Hemoglobin Ibu Hamil dengan Lingkar Kepala Bayi Baru Lahir di RSUP H. Adam Malik Medan. Universitas Sumatera Utara. 2010

6. Darmawan M, Wira S. Faktor Risiko Bayi Berat Badan Lahir Rendah di RS PKU Muhammadiyah Yogyakarta. Universitas Islam Indonesia. 2010

7. Ulfa RP. Hubungan Anemia pada Ibu Hamil Trimester Ketiga dengan Antropometri Bayi Baru Lahir. 2014. Medan: Universitas Sumatra Utara

8. Anggi S, Nur Indrawaty L, Amirah Zatil I. Hubungan antara kadar hemoglobin ibu hamil trimester III dengan berat bayi lahir. Jurnal Kedokteran Andalas. 2013; 2

9. Makhoul Z. Anemia and iron deficiency in rural nepali pregnant women: risk factors, effect of vitamin $A$ supplementation and their association with birth outcomes. Dissertation. University of Arizona. 2009

10. Wang J dkk. Study on the third trimester hemoglobin concentrations and the risk of low birth weight and preterm delivery. PubMed. 2009; 28(1): 15-8

11. Nurkhasanah. Hubungan Status Protein, Besi, Seng, Vitamin A, Folat dan Antrophometri Ibu Hamil Trimester Ildengan Bayi Berat Lahir Rendah. 2013. Semarang: Universitas Diponegoro

12. Laflamme EM. Maternal hemoglobin concentration and pregnancy outcome: a study of the effects of elevation in El Alto, Bolivia. MJM. 2010; 13(1): 47-55

13. Rolla D. Faktor Risiko Anemia Ibu Hamil Terhadap Panjang Badan Lahir Pendek di Puskesmas Sentolo 1 Kulon Progo D.I Yogyakarta. Yogyakarta. 2018. 